\begin{tabular}{|c|c|c|c|c|c|}
\hline JRL & Vol. 13 & No.2 & Hal. 138-151 & $\begin{array}{c}\text { Jakarta, } \\
\text { Desember 2020 }\end{array}$ & $\begin{array}{r}\text { p-ISSN : 2085.38616 } \\
\text { e-ISSN : 2580-0442 }\end{array}$ \\
\hline
\end{tabular}

\title{
ANALISIS KUALITAS AIR DI RUAS SUNGAI BATANG TORU DENGAN METODE STORET DAN INDEKS PENCEMARAN
}

\author{
Taty Hernaningsih \\ Pusat Teknologi Lingkungan, Badan Pengkajian dan Penerapan Teknologi \\ e-mail : tati.hernaningsih@bppt.go.id
}

\begin{abstract}
Abstrak
Kegiatan yang berkembang di sepanjang Sungai Batang Toru akan berpengaruh terhadap kualitas air sungai, karena limbah buangan dari kegiatan tersebut sebagian besar langsung dibuang disungai dan hanya sedikit yang mengolah air limbah sebelum dibuang di sungai seperti air limbah dari Perusahaan tambang emas Martabe. Penelitian ini bertujuan untuk analisis kualitas air di ruas Sungai Batang Toru dengan metoda STORET dan Indeks Pencemaran (IP) seperti yang tercantum dalam Keputusan Menteri Negara Lingkungan Hidup No. 115 tahun 2003. Data parameter kualitas air berasal PT Agincourt Resources (PTAR) yang merupakan hasil pemantauan terhadap 6 lokasi dengan pengambilan data pada periode tahun 2017-2019. Parameter yang dipantau dalam penelitian ini sesuai dengan Keputusan Menteri Lingkungan Hidup Nomor 202 Tahun 2004 yaitu pH, TSS, $\mathrm{CN}$ free, $\mathrm{As}, \mathrm{Cd}, \mathrm{Cr}, \mathrm{Cu}, \mathrm{Fe}, \mathrm{Pb}, \mathrm{Hg}$, Ni dan $\mathrm{Zn}$. Data hasil analisis kualitas air di laboratorium akan dibandingkan dengan baku mutu di PP Nomor 82 Tahun 2001 untuk peruntukan air kelas II dan hasilnya menunjukkan bahwa 11 parameter memenuhi baku mutu dan hanya konsentrasi TSS yang sebagian besar tidak memenuhi baku mutu tersebut. Berdasarkankan perhitungan dengan metode STORET didapat skor bernilai - 8 di semua lokasi sampling maka disimpulkan di ruas sungai Batang Toru lokasi BT1, BT2, BT3, BT4, BT5 dan BT6 tercemar ringan. Perhitungan dengan metode IP terhadap kualitas air di ruas sungai Batang Toru lokasi BT1, BT2, BT3, BT4, BT5 dan BT6 adalah cemar ringan. Kedua metode ini mempunyai kesamaan hasil yaitu kualitas air di ruas sungai Batang Toru telah tercemar ringan.
\end{abstract}

Kata Kunci : Meetode Storet, Indeks, Pencemaran

Analisis Kualitas Air.... JRL Vol. 13 No. 2, Desember, 2020 : 138 - 151 


\title{
ANALYSIS OF WATER QUALITY IN BATANG TORU RIVER WITH STORET AND POLLUTION INDEX METHODS
}

\begin{abstract}
Activities that develop along the Batang Toru River will affect the quality of river water, because most of the waste waste from these activities directly discharged into rivers and only a few treat wastewater before dischargng into the river such as wastewater from the Martabe Gold Mine. This study aims to analyze the quality of water in the Batang Toru River section using the STORET method and the Pollution Index (IP) as stated in the Decree of the State Minister for the Environment No. 115 of 2003. Water quality parameter data comes from PT Agincourt Resources (PTAR) which is the result of monitoring 6 locations with data collection in the 2017-2019 period. The parameters monitored in this study are in accordance with the Decree of the Minister of Environment Number 202 of 2004, namely pH, TSS, CN free, As, Cd, Cr, Cu, Fe, Pb, $\mathrm{Hg}$, Ni and $\mathrm{Zn}$. The data from the analysis of water quality in the laboratory will be compared with the quality standard in Government Regulation No. 82 of 2001 for class II water designation and the results show that 11 parameters meet the quality standard and only TSS concentration mostly do not meet these quality standards. Based on the calculation using the STORET method, it was obtained a score of -8 in all sampling locations, so it was concluded that in the Batang Toru river section, locations BT1, BT2, $B T 3, B T 4, B T 5$ and BT6 were lightly polluted. Calculations using the IP method of water quality in the Batang Toru river section at locations BT1, BT2, BT3, BT4, BT5 and BT6 are lightly polluted. Both of these methods have the same results, namely the water quality in the Batang Toru river segment has been lightly polluted.
\end{abstract}

Key word : Storet Method, Pullution Index, 


\section{PENDAHULUAN}

\subsection{Latar Belakang}

Kawasan Batang Toru terdapat berbagai macam penggunaan lahan, diantaranya perkebunan, pertambangan, jalan raya, komersil, perkantoran dan pemukiman. Proyek PLTA Batang Toru yang mempunyai kegiatan di lahan tersebut juga didominasi kebun karet (UNEP, 2011). Selain itu perusahaan Perusahaan tambang emas Martabe juga mengunakan lahan kawasan tersebut dan telah mendapat ijin kegiatan sekitar $130.252 \mathrm{Ha}$ tanggal $24 \mathrm{Mei}$ 2018.

Penggunaan lahan tersebut menyebabkan perubahan lingkungan pada biologi seperti satwa liar yang berada di hutan-hutan di kawasan Batang Toru terpisah antara yang satu dengan lainnya. Perubahan lainnya juga terjadi pada sumber air yang terdapat dikawasan ini. Dalam Kawasan Batang Toru terdapat Sungai Batang Toru yang merupakan sungai utama yang berhulu di Tarutung Kabupaten Humbang Hasundutan dan berhilir di Samudera Indonesia. Sungai Batang Toru adalah salah satu sungai terbesar di Tapanuli Selatan dengan panjang 69,32 Km. Sungai ini merupakan induk sungai yang terbentuk dari Sungai Aek Pahu Tombak dan Aek Pahu Hutamosu. Dari sisi hidrologi, pola aliran sungai di Ekosistem Batang Toru mengikuti pola paralel. Sungai Batang Toru, Aek Pahu Tombak dan Aek Pahu Hutamosu banyak dimanfaatkan oleh penduduk dalam kehidupan sehari-hari untuk kebutuhan pertanian, perkebunan, industri berupa pertambangan emas dan tempat pembuangan limbah dari rumah tangga(H.Sirait, 2013)

Laju aliran alami Sungai Batang Toru adalah antara $41,9-484 \mathrm{~m}^{3} /$ detik, dengan laju terendah pada Juli Agustus 2018 sebesar $84 \mathrm{~m}^{3} /$ detik. Laju aliran ini bervariasi dari hari ke hari. Pada tanggal 23 September 2018, Iaju aliran dapat mencapai 514 $\mathrm{m}^{3} /$ detik dan beberapa desa di hilir dapat terkena dampaknya (PT Agincourt Resources, 2020).

Selain dimanfaatkan untuk kepentingan penduduk, Sungai Batang Toru menerima air limbah dari hasil kegiatan yang berkembang di lingkungan sekitarnya. Air limbah ini ada yang langsung dibuang ke sungai tanpa diolah atau ada yang sudah diolah lebih dahulu sebelum dibuang ke sungai tersebut. Sumber air limbah diantaranya berasal dari kegiatan pengambilan bahan galian golongan $\mathrm{C}$ di Sungai Batang Toru, air limbah penduduk, air limbah dari semua kegiatan yang ada di sepanjang sungai Batang Toru dan air limbah yang sudah diolah dari perusahaan perusahaan tambang emas Martabe.

PT Agincourt Resource sebagai pengelola perusahaan tambang emas Martabe telah memantau kualitas air limbah yang sudah diolah tersebut dan kualitas air di ruas sungai yang menerima air limbah olahan secara periodik, Lokasi pemantauan kualitas air dilakukan pada ruas Sungai Batang Toru sebelum dan sesudah pipa efluen serta di efluen dari perusahaan tambang emas tersebut.

Sampel air dari proses kegiatan perusahaan tambang emas Martabe yang dibuang ke sungai Batang Toru dan air Sungai Batang Toru telah diuji di laboratorium terakreditasi PT Intertek Utama Services, di Bogor. Dari hasil uji laboratorium disimpulkan bahwa kualitas air limbah yang telah diolah di IPAL memenuhi nilai baku mutu yang disyaratkan KepMenLH No 202/2004 dan kualitas air Sungai Batang Toru memenuhi nilai baku mutu yang disyaratkan dalam Peraturan Pemerintah 82/2001 Kelas II dengan menggunakan parameter yang sama dengan 12 parameter yang digunakan dalam KepMenLH No. 
202/2004. Hal ini menunjukkan bahwa air dari proses pengolahan air limbah perusahaan tambang emas Martabe yang dialirkan ke Sungai Batang Toru, Kabupaten Tapanuli Selatan tidak memberikan dampak bagi kualitas air Sungai Batang Toru.

Pemantauan di Sunga Batang Toru yang telah dilakukan hanya membandingkan kualitas parameter dengan baku mutu kelas air namun belum dilakukan kajian lebih lanjut mengenai kondisi pencemaran Sungai Batang Turo. Berdasarkan hasil tersebut hanya dapat ditentukan kualitas air sungai di tiap lokasi sampling Sungai Batang Toru. Padahal untuk pemangku kebijakan agar dapat membuat strategi pengelolaan Sungai Batang Toru harus diketahui tingkat pencemaran air sungai yang telah terjadi.

Untuk mengetahui tingkat pencemaran air sungai dapat dilakukan dengan menggunakan modeling kualitas air, namun cara ini memerlukan pengetahuan mendalam tentang hidrolika dan hidrodinamika 2 serta validasi yang ketat (Pesce and Wunderlin, 2000). Selain menggunakan modeling kualitas air dapat digunakan metode lain yaitu pendekatan secara analisis statistik dari berbagai parameter yang ada menjadi sistem indeks kualitas air. Indeks kualitas air lebih digunakan karena dapat memberikan suatu nilai yang mencakup pengukuran banyak parameter pencemar dengan cara yang sederhana dan dapat diinterpretasikan dengan mudah.

Penggunaan indeks kualitas air dapat disesuaikan pada wilayah yang berbeda-beda (Bharti and Katyal, 2011). Di indonesia, metode evaluasi kualitas badan air dengan indeks kualitas air diatur dalam Keputusan Menteri Negara Lingkungan Hidup No. 115 tahun 2003 tentang pedoman penentuan status mutu air. Di dalam pasal 2 Keputusan Menteri Negara Lingkungan Hidup No. 115 tahun 2003 dijelaskan penentuan status mutu air dapat dilakukan dengan metode STORET atau Metode Indeks Pencemaran (IP). Secara prinsip metode STORET dan IP adalah membandingkan antara data kualitas air dengan kelas air yang disesuaikan dengan peruntukannya guna menentukan status mutu air.

Untuk keperluan ini maka diperlukan penelitian dalam menentukan kualitas air pada Sungai Batang Toru. Oleh karena itu makalah ini bertujuan untuk analisis setiap parameter kualitas air dengan memibandingkan dengan baku mutu Peraturan Pemerintah 82/2001 Kelas II dan menganalisis kualitas air Sungai Batang Toru Hilir dengan menggunakan Metode STORET dan Indeks Pencemaran.

\section{METODOLOGI PENELITIAN}

Penelitian dimulai dengan pengumpulan data primer yang diperlukan untuk kualitas air sungai. Data yang diperlukan untuk evaluasi didapat dari PTAR yang telah mengambil sampel air di beberapa titik sungai secara periodik.

Lokasi pengambilan sampel pada Sungai Batang Toru di bagi menjadi 6 lokasi sampling dengan dasar posisi pipa buangan air limbah dari PTAR dan kualitas air sebelum serta setelah posisi pipa buangan tersebut. Secara spesifik lokasi pengambilan sampel kualitas air di ruas Sungai Batang Toru dijelaskan pada tabel 1. 
Tabel 1. Lokasi Pemantauan Kualitas Air di Ruas Sungai Batang Toru

\begin{tabular}{|c|l|}
\hline $\begin{array}{c}\text { No. } \\
\text { Sampel }\end{array}$ & Lokasi Sampel \\
\hline BT1 & $\begin{array}{l}500 \text { meter hulu pipa } \\
\text { outlet }\end{array}$ \\
\hline BT2 & Outfall 30 m hilir Pipa \\
\hline BT3 & 500 meter hilir pipa \\
\hline BT4 & 1.000 meter hilir pipa \\
\hline BT5 & 2.000 meter hilir pipa \\
\hline BT6 & 3.000 meter hilir pipa \\
\hline
\end{tabular}

Sumber: PT Agincourt Resources (2020)

Penentuan lokasi ini ditujukan untuk mengambil sampel air yang dapat mewakili kualitas air pada Sungai Batang Toru sebelum dan sesudah pipa efluen dan di pipa efluan air dari proses kegiatan penambangan PTAR. Peta lokasi pemantauan kualitas air di ruas sungai Batang Toru dapat dilihat pada gambar 1 .

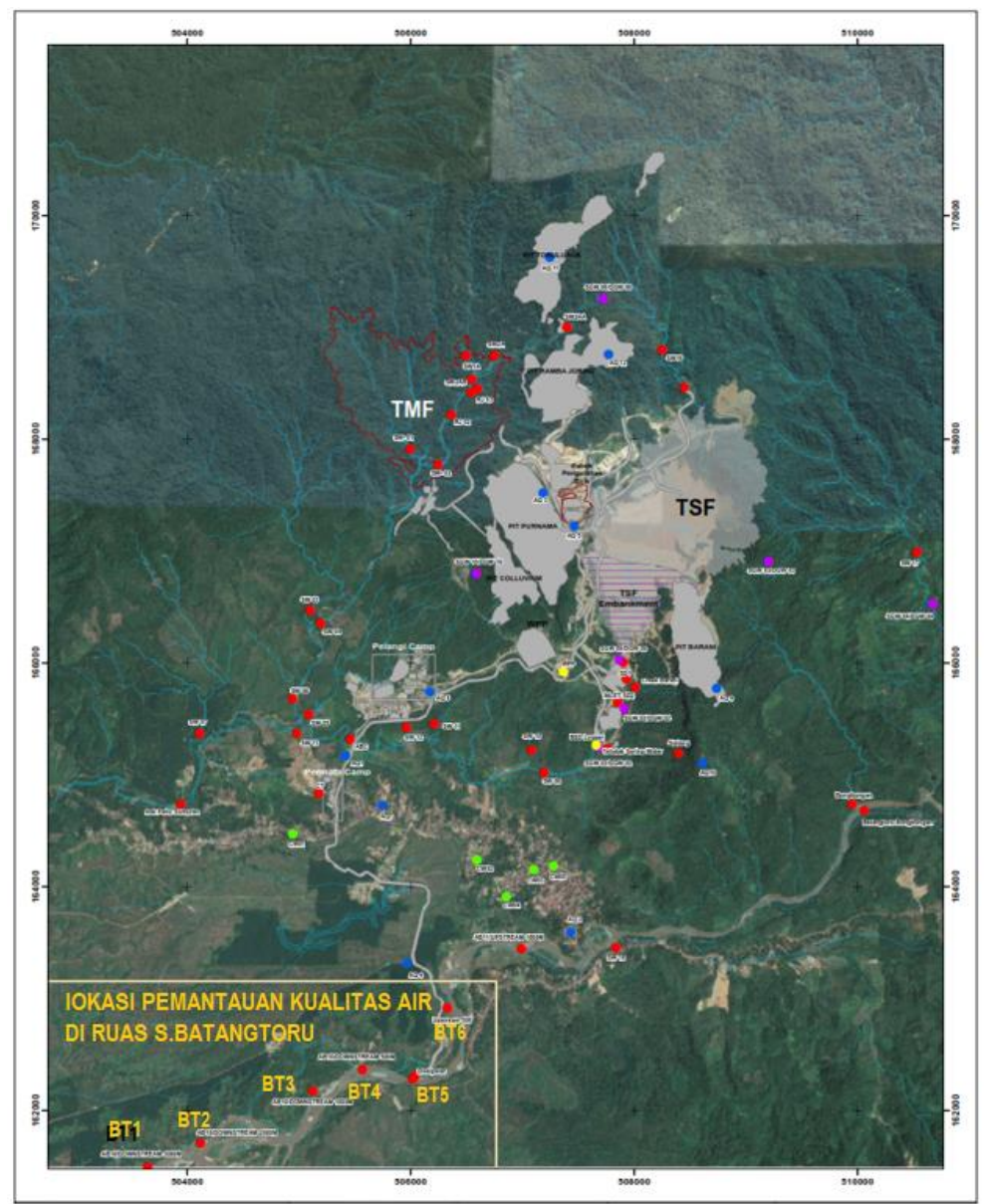

Sumber: PT Agincourt Resources (2020)

Gambar 1. Peta Lokasi Pemantauan Kualitas Air di Ruas Sungai Batang Toru 


\subsection{Metode Pengumpulan Data}

Data dikumpulkan dari hasil pemantauan kualitas air di ruas Sungai Batang Toru yang telah dilakukan PT Agincourt Resources(PTAR) tahun 20172019. Parameter yang dipantau dalam penelitian sesuai dengan Keputusan Menteri Lingkungan Hidup Nomor 202 Tahun 2004, yaitu 12 parameter air terdiri atas $\mathrm{pH}, \mathrm{TSS}, \mathrm{CN}$ free, As, $\mathrm{Cd}, \mathrm{Cr}, \mathrm{Cu}$, $\mathrm{Fe}, \mathrm{Pb}, \mathrm{Hg}, \mathrm{Ni}$ dan $\mathrm{Zn}$.

Data hasil analisis kualitas air dari laboratorium akan dibandingkan dengan baku mutu yang harus dipenuhi dalam PP No. 82 Tahun 2001 untuk peruntukan air kelas II.

Metode analisis kualitas badan air dilakukan berdasarkan indeks kualitas air yang diatur dalam Keputusan Menteri Negara Lingkungan Hidup No. 115 tahun 2003 tentang pedoman penentuan status mutu air. Di dalam pasal 2 Keputusan Menteri Negara Lingkungan Hidup No. 115 tahun 2003 dinyatakan bahwa penentuan status mutu air dapat dilakukan dengan metode STORET atau Metode Indeks Pencemaran (IP).

\subsection{Metode Analisis Data}

Status kualitas air adalah tingkat kondisi mutu air yang menunjukkan kondisi cemar atau kondisi baik pada suatu sumber air dalam waktu tertentu dengan membandingkan dengan baku mutu air yang ditetapkan. Untuk mengetahui kondisi kualitas air limbah yang telah diolah dari Perusahaan tambang emas Martabe dan dialirkan ke Sungai Batang Toru, telah dilakukan dengan membandingkan dengan baku mutu Peraturan Pemerintah No 82 Tahun 2001 tentang pengelolaan kualitas air dan pengendalian pencemaran air.

Cara untuk menentukan status mutu air pada metode STORET adalah dengan menggunakan sistem nilai dari "US-EPA (Environmental Protection Agency) dengan mengklasifikasikan mutu air dalam kelas II. Sedangkan pada metode IP ditentukan dari resultan nilai maksimum dan nilai rata-rata rasio konsentrasi per paramater terhadap nilai baku mutunya. Parameter yang digunakan dalam penelitian ini adalah yaitu $\mathrm{pH}$, TSS, CN free, As, $\mathrm{Cd}, \mathrm{Cr}, \mathrm{Cu}, \mathrm{Fe}$, $\mathrm{Pb}, \mathrm{Hg}, \mathrm{Ni}$ dan $\mathrm{Zn}$.

Selanjutnya dihitung mutu air dengan menggunakan dan Metode STORET dan Indeks Polusi dengan menggunakan data hasil pemantauan. Analisis dilakukan sesuai dengan Peraturan Pemerintah No 82 Tahun 2001 tentang pengelolaan kualitas air dan pengendalian pencemaran air.

Berdasarkan Peraturan Pemerintah No. 82 Tahun 2001 Pasal 1 mutu air bahwa kondisi kualitas air yang diukur dan atau diuji berdasarkan parameterparameter tertentu dan metode tertentu sesuai peraturan perundang - undangan yang berlaku. Sedangkan baku mutu air adalah ukuran batas atau kadar makhluk hidup, zat, energi, atau komponen yang ada atau harus ada atau unsur pencemar yang ditenggang keberadaannya di dalam air. Kelas air adalah peringkat kualitas air yang dinilai masih layak untuk dimanfaatkan bagi peruntukan tertentu. 


\section{Metode STORET}

Metode STORET merupakan salah satu metode yang akan digunakan untuk menentukan status mutu air. Penentuan status mutu air dilakukan dengan cara membandingkan data kualitas air dengan baku mutu yang telah ditetapkan sesuai dengan peruntukannya. Dengan metode ini dapat diketahui parameterparameter yang telah memenuhi atau melampaui baku mutu air.

Cara menentukan status mutu air digunakan sistem nilai dari US-EPA (Environmental Protection Agency) dengan mengklasifikasikan mutu air dalam empat kelas seperti pada tabel 3 . (Kepmen LH No. 115, 2003).

Penentuan status mutu air dengan menggunakan metode STORET dilakukan dengan langkah-langkah sebagi berikut :

1. Melakukan pengumpulan data mutu air secara periodik sehingga membentuk data dari waktu ke waktu (time series data).

2. Mencari nilai maksimum, minimum dan rata-rata dari data mutu air tersebut.

3. Membandingkan data hasil pengukuran dari masingmasing parameter air dengan nilai baku mutu yang sesuai dengan kelas air.

4. Jika hasil pengukuran memenuhi nilai baku mutu air (hasil pengukuran < baku mutu) maka diberi skor 0 .

5. Jika hasil pengukuran tidak memenuhi nilai baku mutu air (hasil pengukuran > baku mutu), maka di beri skor sesuai dengan Tabel 2.
Tabel 2. Penentuan Sistem Nilai untuk Menentukan Status Mutu Air

\begin{tabular}{|c|c|c|c|c|}
\hline Jumlah & \multirow{2}{*}{ Contoh* $^{*}$} & \multicolumn{3}{|c|}{ Nilai } \\
\cline { 3 - 5 } & & Fisika & Kimia & Biologi \\
\hline \multirow{3}{*}{$<10$} & Maks & -1 & -2 & -3 \\
\cline { 2 - 5 } & Min & -1 & -2 & -3 \\
\cline { 2 - 5 } & Rerata & -3 & -6 & -9 \\
\hline \multirow{2}{*}{$\geq 10$} & Maks & -2 & -4 & -6 \\
\cline { 2 - 5 } & Min & -2 & -4 & -6 \\
\cline { 2 - 5 } & Rerata & -6 & -12 & -18 \\
\hline
\end{tabular}

Sumber : Canter (1977)

Catatan*: jumlah parameter yang digunakan untuk penentuan status mutu air.

6. Menghitung total jumlah negatif dari seluruh parameter dengan menggunakan status mutu airnya dengan melihat Tabel 3

Tabel 3. Klasifikasi Status Mutu Air Menurut "US-EPA"

\begin{tabular}{|c|c|c|c|c|}
\hline No & $\begin{array}{c}\text { Kela } \\
\text { s }\end{array}$ & Kategori & Skor & Ket \\
\hline 1 & $\begin{array}{c}\text { Kelas } \\
\text { A }\end{array}$ & $\begin{array}{c}\text { Baik } \\
\text { Sekali }\end{array}$ & 0 & $\begin{array}{c}\text { Memenuhi } \\
\text { baku mutu }\end{array}$ \\
\hline 2 & $\begin{array}{c}\text { Kelas } \\
\text { B }\end{array}$ & Baik & -1 s/d -10 & $\begin{array}{c}\text { Tercemar } \\
\text { ringan }\end{array}$ \\
\hline 3 & $\begin{array}{c}\text { Kelas } \\
\text { C }\end{array}$ & Sedang & $\begin{array}{c}-11 \mathrm{~s} / \mathrm{d}- \\
30\end{array}$ & $\begin{array}{c}\text { Tercemar } \\
\text { sedang }\end{array}$ \\
\hline 4 & $\begin{array}{c}\text { Kelas } \\
\text { D }\end{array}$ & Buruk & $\geq-30$ & $\begin{array}{c}\text { Tercemar } \\
\text { berat }\end{array}$ \\
\hline
\end{tabular}

Sumber : Kepmen LH No. 115, 2003.

\section{Metode Indeks Pencemaran}

Metode kedua yang

direkomendasikan oleh Permen LH No 115 Tahun 2003 dan dikembangkan oleh Sumitomo dan Nemerow (1970) pada Universitas Texas yaitu suatu indeks yang berkaitan dengan senyawa pencemar pada suatu peruntukan. Indeks ini dikenal dengan Indeks Pencemaran (Pollution Indeks) 
yang digunakan untuk menentukan tingkat pencemaran relatif terhadap parameter kualitas air yang diizinkan. Pengelolaan kualitas air atas dasar Indeks Pencemaran dapat memberikan masukan pada pengambil keputusan agar dapat menilai kualitas badan air untuk suatu peruntukan serta melakukan tindakan untuk memperbaiki kualitas jika terjadi penurunan kualitas perairan akibat kehadiran senyawa pencemar.

Perhitungan IP sesuai dengan pedoman yang ada pada Keputusan Menteri Negara Lingkungan Hidup No. 115 tahun 2003 dilakukan sesuai dengan prosedur berikut:

1. Menghitung harga $\mathrm{Ci} / \mathrm{Lij}$ untuk tiap parameter pada setiap lokasi pengambilan sampel dengan $\mathrm{Ci}$ adalah konsentrasi hasil pengukuran dan Lij adalah baku mutu yang harus dipenuhi dalam PP No. 82 Tahun 2001 untuk peruntukan air kelas II.

2. Jika nilai konsentrasi parameter yang menurun menyatakan tingkat pencemaran meningkat, misal DO. Tentukan nilai teoritik atau nilai maksimum Cim (misal untuk DO, maka Cim merupakan nilai DO jenuh). Dalam kasus ini digunakan Persamaan (1), nilai $\mathrm{Ci} / \mathrm{Lij}$ hasil pengukuran digantikan oleh nilai $\mathrm{Ci} / \mathrm{Lij}$ hasil perhitungan.

$$
\begin{gathered}
\left(\frac{C i}{L i j}\right) \text { baru }= \\
\frac{\text { Cim-Ci(hasil pengukuran })}{\text { Cim-Lij }}
\end{gathered}
$$

Jika nilai baku mutu Lij memiliki rentang, maka :

- untuk Ci < Lij rata-rata digunakan Persamaan (2).

$$
\begin{aligned}
& \left(\frac{C i}{L i j}\right) \text { baru }= \\
& \frac{C j-L i j(\text { rata-rata })}{[\text { Lij(minimum })-L i j(\text { rata-rata })]} \\
& \ldots(2) \\
& \text { - untuk Ci > Lij rata-rata } \\
& \text { digunakan Persamaan }
\end{aligned}
$$
(3).

$$
\begin{gathered}
\left(\frac{C i}{L i j}\right) \text { baru }= \\
\frac{C j-L i j(\text { rata-rata })}{[\text { Lij(maksimum })-L i j(\text { rata }- \text { rata })]}
\end{gathered}
$$

Jika dua nilai (Ci/Lij) berdekatan dengan nilai acuan 1,0, misal $\mathrm{C} 1 / \mathrm{L} 1 \mathrm{j}=0,9$ dan C2/L2 $\mathrm{j}=1,1$ atau perbedaan yang sangat besar, misal C3/L3j = 5,0 dan C4/L4j = 10,0. Dalam contoh ini tingkat kerusakan badan air sulit ditentukan. Cara untuk mengatasi kesulitan ini adalah:

(1) Penggunaan nilai (Ci/Lij) hasil pengukuran kalau nilai ini lebih kecil dari 1,0 .

Penggunaan nilai (Ci/Lij) baru jika nilai (Ci/Lij)hasil pengukuran lebih besar dari 1,0 dengan perhitungan nilai (Ci/Lij)baru dapat dilihat pada Persamaan (4).

$$
\begin{gathered}
\left(\frac{C i}{L i j}\right) \text { baru }=1+ \\
\text { P. } \log \left(\frac{C i}{L i j}\right) \text { hasil pengukuran..(4) }
\end{gathered}
$$

P merupakan konstanta dan nilainya ditentukan dengan bebas dan disesuaikan dengan hasil pengamatan lingkungan dan atau 
persyaratan

dikehendaki

peruntukan

digunakan nilai 5).

untuk suatu

(biasanya

3. Menentukan nilai rata-rata dan

nilai maksimum dari keseluruhan $\mathrm{Ci} / \mathrm{Lij}((\mathrm{Ci} / \mathrm{Lij}) \mathrm{R}$ dan (Ci/Lij)M).

4. Menentukan harga Plj atau IP dengan Persamaan (5).

$$
\mathrm{Pij}=\sqrt{\frac{\left(\frac{C i}{L i j}\right)_{M}^{2}+\left(\frac{C i}{L i j}\right)_{R}^{2}}{2}}
$$

Klasifikasi kriteria kualitas air dengan metode IP dapat dilihat pada Tabel 3.

Tabel 3. Klasifikasi kriteria kualitas air dengan metode IPA (KepMenLH No. 115 Th. 2003).

\begin{tabular}{|c|c|}
\hline Nilai IPA & $\begin{array}{c}\text { Keterangan } \\
\text { Kondisi }\end{array}$ \\
\hline $0 \leq$ Pli $\leq 1,0$ & $\begin{array}{c}\text { Memenuhi baku } \\
\text { mutu(kondisi baik) }\end{array}$ \\
\hline
\end{tabular}

\begin{tabular}{|c|c|}
\hline $0<\mathrm{Pli} \leq 5,0$ & Cemar ringan \\
\hline $5<\mathrm{Pli} \leq 10$ & Cemar sedang \\
\hline $\mathrm{Pli}>10$ & Cemar berat \\
\hline
\end{tabular}

\section{PEMBAHASAN}

\section{Hasil Pengukuran Parameter}

Hasil pengukuran sampel air diambil dari keenam lokasi titik sampel dengan 12 parameter pada tahun 2017-2019 yaitu pH, TSS, CN free, As, $\mathrm{Cd}, \mathrm{Cr}, \mathrm{Cu}, \mathrm{Fe}, \mathrm{Pb}, \mathrm{Hg}$, Ni dan $\mathrm{Zn}$. Konsentrasi $\mathrm{CN}$ free, As, Cd, Cr, Cu, $\mathrm{Pb}, \mathrm{Hg}$, dan $\mathrm{Zn}$ nilainya rendah dan dibawah baku mutu PP No. 82 Tahun 2001 untuk peruntukan air kelas II, sedangkan Ni tidak ada baku mutunya dengan nilainya rendah.

Hasil pengujian lapangan dan laboratorium terhadap $\mathrm{pH}$, TSS, Arsen dan besi dapat dilihat pada gambar 2 sampai 5. Pada gambar 2 dapat dilihat nilai $\mathrm{pH}$ berfluktuasi dan masih memenuhi bentang baku mutu $\mathrm{pH}$ (69).

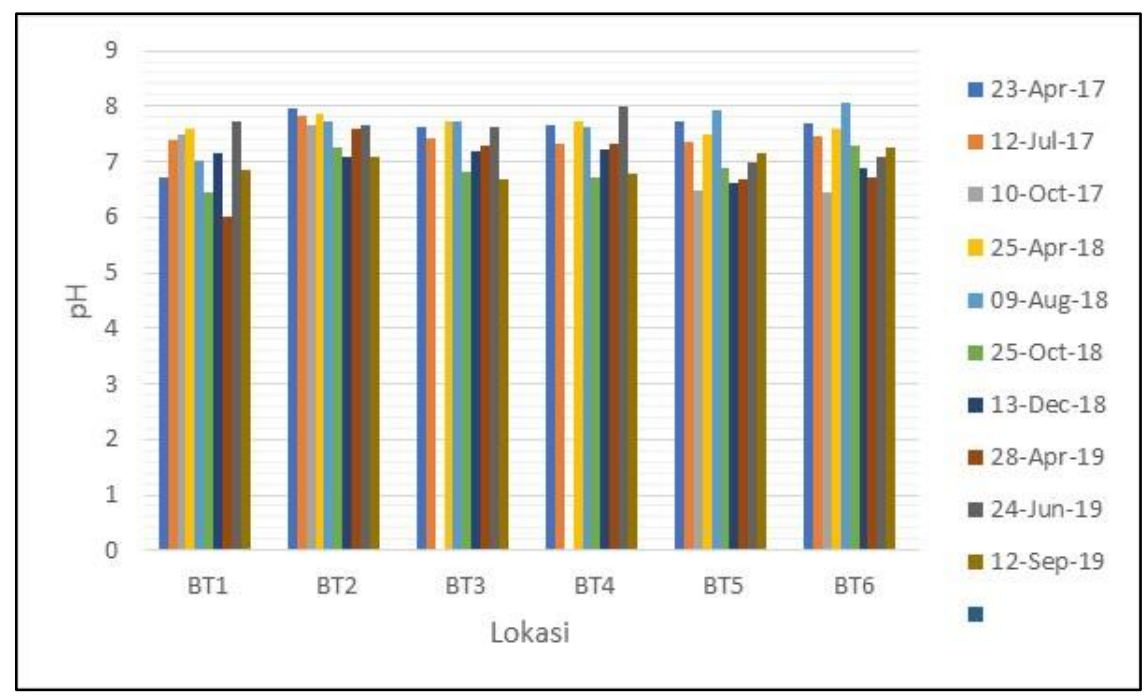

Gambar 2. Konsentrasi pH tahun 2017-2019 
Pada gambar 3 dapat dilihat di lokasi BT1 yang jaraknya $500 \mathrm{~m}$ sebelah hulu sebelum dibuangnya air limbah proses dari Perusahaan tambang emas Martabe, konsentrasi TSS umumnya sudah tinggi dengan nilai TSS sebagian melebihi baku mutu yang ditetapkan PP No.82 Tahun 2001 kelas II (>50 mg/l). Hal ini diakibatkan adanya galian tambang tipe $\mathrm{C}$, sedangkan kualitas TSS dari air di lokasi BT2 sudah memenuhi baku mutu efluen ke badan air sehingga konsentrasi TSS di BT2 lebih rendah dibandingkan TSS di lokasi BT1. Konsentrasi TSS di lokasi BT4 nilainya tertinggi dibandingkan lokasi lainnya, karena adanya masukan air limbah dari disepanjang sungai Batang Toru yang kandungan TSSnya tinggi. Setelah lokasi BT4 tersebut, konsentrasi TSS menurun di BT5 dan BT6.

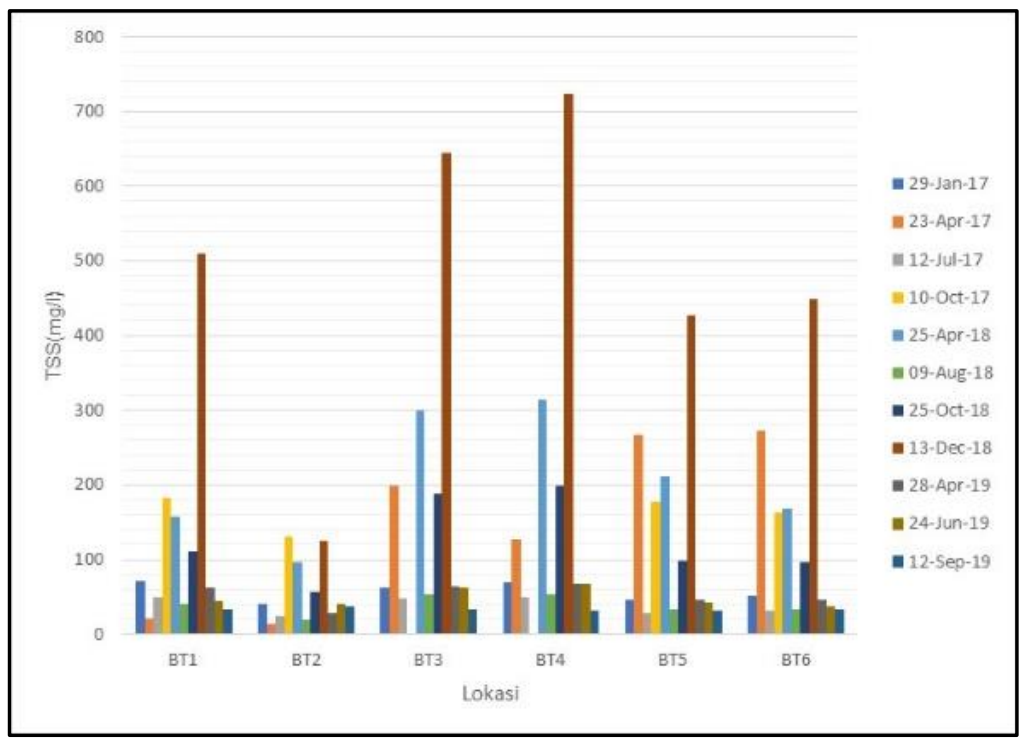

Gambar 3. Konsentrasi TSS tahun 2017-2019

Konsentrasi BT1 di ruas sungai Batang Toru mengandung As dan nilainya bertambah di lokasi BT2 akibat masuknya air limbah olahan dari perusahaan tambang emas PTAR, hal ini menyebabkan kosentrasi As di BT2 lebih tinggi dari lokasi lainnya. Walaupun demikian kosentrasi As di BT2 masih memenuhi baku mutu yang ditetapkan PP No.82 Tahun 2001 kelas II $(<0,5 \mathrm{mg} / \mathrm{l})$. 


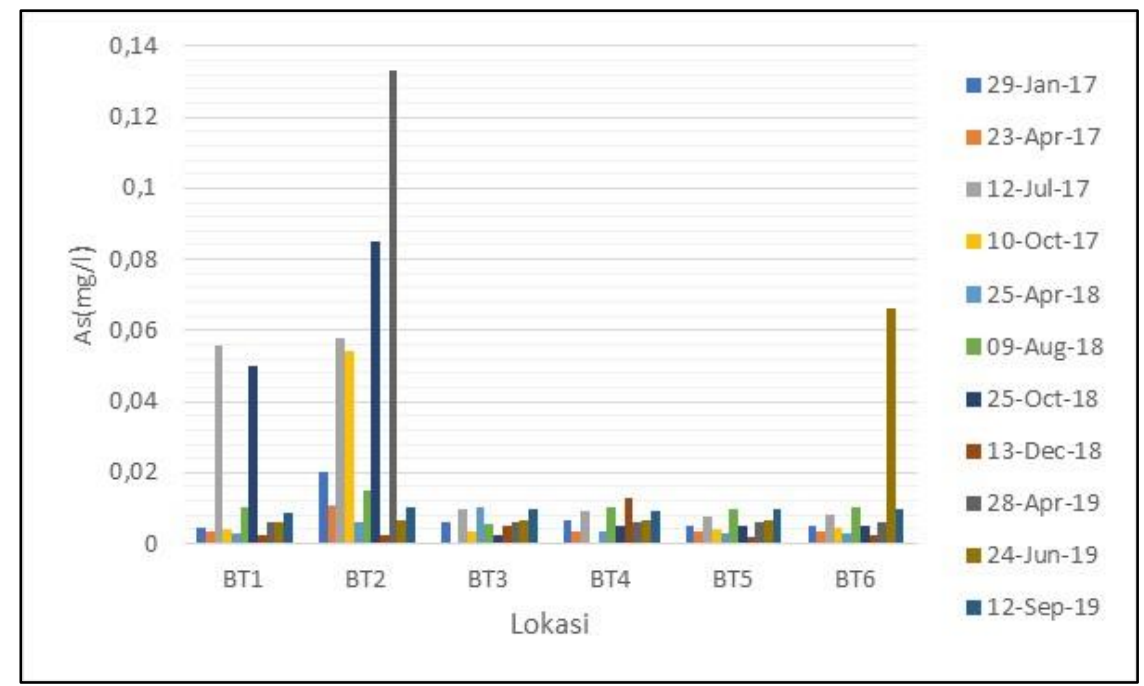

Gambar 4. Konsentrasi As tahun 2017-2019

Di ruas sungai Batang Toru mengandung Fe dengan nilai yang bervariasi yang disebabkan kondisi geologi setempat.
Sedangkan parameter $\mathrm{Fe}$ ini tidak ada baku mutunya menurut PP No.82 Tahun 2001 kelas II.

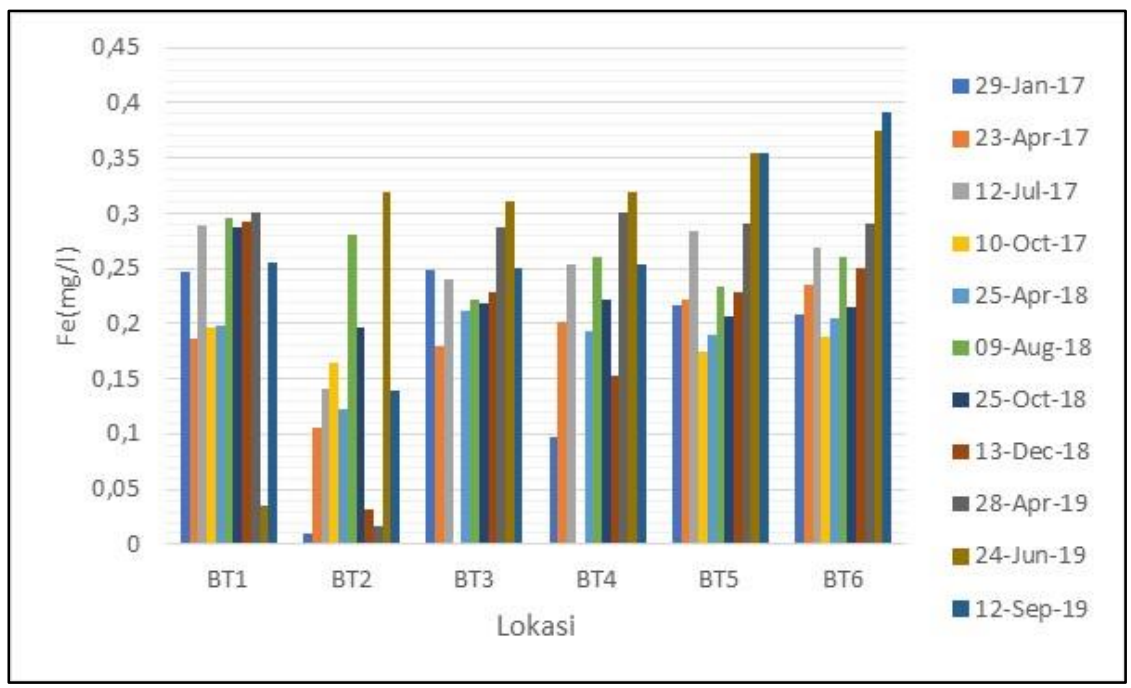

Gambar 4. Konsentrasi Fe tahun 2017-2019

$\begin{array}{lccl}\begin{array}{l}\text { Perhitungan Nilai } \\ \text { STORET }\end{array} \text { dan } & \begin{array}{c}\text { Indeks } \\ \text { Indeks }\end{array} & \begin{array}{l}\text { diperlukan sudah didapatkan, hasil } \\ \text { pengukuran parameter digunakan } \\ \text { Pencemaran (IP) }\end{array} \\ \begin{array}{l}\text { Setelah semua } \\ \text { untuk perhitungan dengan metode }\end{array} \\ \begin{array}{l}\text { pengukuran parameter } \\ \text { hang }\end{array} & \begin{array}{l}\text { STORET dan indeks pencemaran } \\ \text { sesuai yang dijabarkan pada }\end{array}\end{array}$


bagian metodologi. Pada pengukuran parameter dan perhitungan STORET dan IP, perhitungan dengan indeks baku mutu air yang digunakan STORETdi ruas Sungai Batang adalah lampiran PP no 82 tahun Toru, hasilnya dapat disampaikan 2001 kelas II.

Berdasarkan

hasil pada Gambar 4.

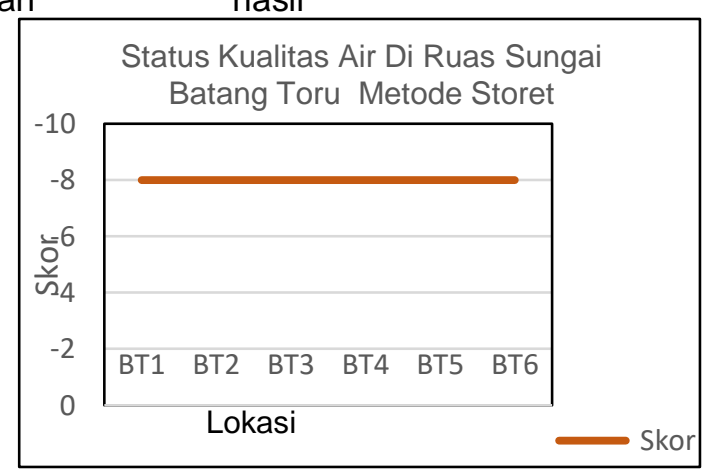

Gambar 4. Hasil Perhitungan Kualitas Air Sungai Batang Toru dengan Metode STORET

Menurut metode ini, semakin rendah nilai indeksnya berkurang cemarannya. Nilai indeks pada lokasi BT1 sampai BT6 nilainya sama yaitu - 8 dan nilai ini menunjukkan semua lokasi mengalami cemar ringan karena adanya konsentrasi TSS yang melebihi baku mutu.

Perubahan nilai indeks pencemaran di ruas Sungai Batang Toru dapat dilihat pada Tabel 4. Menurut metode ini, semakin besar nilai indeksnya artinya badan air semakin tercemar. Di sungai ini, nilai IP terendah di BT2 sebesar 0,99 dan tertinggi di BT4 sebesar 2,90. Dari tabel dapat dilihat bahwa lokasi BT1, BT2, BT3, BT4, BT5 dan BT6 mempunyai nilai IP rata-rata 2,27 atau dibawah 5 yang berarti kualitas air mengalami cemar ringan. Berdasarkan nilai IP, maka lokasi BT2 atau lokasi Sungai Batang Toru menunjukkan kualitas yang paling sedikit mengalami pencemaran dibandingkan lokasi lain sehingga dapat dinyatakan air limbah olahan dari Perusahaan tambang emas Martabe tidak memberikan dampak negatif terhadap Sungai Batang Toru. 
Tabel 4. Hasil Perhitungan Rata-Rata Ci/Lij Baru (Baku Mutu PP 82 tahun 2001 kelas II)

\begin{tabular}{|l|c|c|c|c|c|c|}
\hline \multirow{2}{*}{ Parameter } & \multicolumn{7}{|c|}{ Lokasi Pemantauan } & & \\
\cline { 2 - 7 } & BT1 & BT2 & BT3 & BT4 & BT5 & BT6 \\
\hline $\mathrm{pH}$ & 0,25 & 0,07 & 0,16 & 0,07 & 0,27 & 0,20 \\
$\mathrm{TSS}$ & 1,76 & 1,24 & 6,55 & 3,66 & 3,05 & 3,00 \\
\hline $\mathrm{CN}$ free & 0 & 0 & 0 & 0 & 0 & 0 \\
$\mathrm{As}$ & 0 & 0 & 0 & 0 & 0 & 0 \\
$\mathrm{Cd}$ & 0 & 0 & 0 & 0 & 0 & 0 \\
$\mathrm{Cr}$ & 0 & 0 & 0 & 0 & 0 & 0 \\
$\mathrm{Cu}$ & 0 & 0 & 0 & 0 & 0 & 0 \\
$\mathrm{Fe}$ & - & - & - & - & - & - \\
$\mathrm{Pb}$ & 0 & 0 & 0 & 0 & 0 & 0 \\
$\mathrm{Hg}$ & 0 & 0 & 0 & 0 & 0 & 0 \\
$\mathrm{Ni}$ & - & - & - & - & - & - \\
$\mathrm{Zn}$ & 0 & 0 & 0 & 0 & 0 & 0 \\
\hline Pij & $\mathbf{2 , 1 3}$ & $\mathbf{0 , 9 9}$ & $\mathbf{2 , 7 5}$ & $\mathbf{2 , 9 0}$ & $\mathbf{2 , 4 6}$ & $\mathbf{2 , 4 0}$ \\
\hline Katagori & Cemar ringan & Cemar ringan & Cemar ringan & Cemar ringan & Cemar ringan & Cemar ringan \\
\hline Pij rata-rata & $\mathbf{2 , 2 7}$ & (Cemar ringan) & & \\
\hline
\end{tabular}

\section{KESIMPULAN}

Berdasarkan hasil pemantauan terhadap 6 lokasi di ruas sungai Batang tahun 2017-2019 yaitu BT1, Bt2, BT3, BT4, BT5 dan BT6 terhadap 12 parameter dapat disimpulkan bahwa 11 parameter yaitu $\mathrm{pH}, \mathrm{CN}$ free, $\mathrm{As}, \mathrm{Cd}, \mathrm{Cr}, \mathrm{Cu}, \mathrm{Fe}, \mathrm{Pb}, \mathrm{Hg}$, Ni dan $\mathrm{Zn}$ memenuhi baku mutu Peraturan Pemerintah No.82 Tahun 2001 baku mutu kelas II, sedangkan beberapa konsentrasi TSS melebihi baku mutu. Jika dilihat dari masing masing lokasi, dapat disimpulkan bahwa lebih dari separuh dari jumlah sampel di lokasi BT1 konsentrasi TSS sudah melebihi baku mutu, di lokasi BT2 konsentrasinya menurun dan konsentrasi di BT4 paling tinggi dibandingkan di lokasi lainnya, karena adanya masuknya aliran air yang konsentrasi TSS nya tinggi.

Dengan menggunakan metode STORET dan membandingkan semua parameter sesuai Peraturan Pemerintah No.82 Tahun 2001 baku mutu kelas II didapat skor bernilai -8 di semua lokasi sampling di Sungai
Batang Toru. Oleh karena itu disimpulkan di ruas sungai Batang Toru lokasi BT1, BT2, BT3, BT4, BT5 dan BT6 adalah tercemar ringan.

Setelah dihitung dengan metode IP dan membandingkan semua parameter sesuai Peraturan Pemerintah No.82 Tahun 2001 baku mutu kelas II, dihasilkan semua nilai IP dibawah 5 di lokasi sampling BT1, BT2, BT3, BT5 dan BT6. Jadi dapat disimpulkan bahwa lokasi penelitian di ruas sungai Batang Toru adalah cemar ringan

Dari kedua metode yang digunakan menunjukkan bahwa pencemaran kualitas air terdapat kesamaan yaitu tingkat pencemaran di ruas Sungai Batang Toru (BT1, BT2, BT3, BT4, BT5 dan BT6) dengan status kualitas airnya tercemar ringan.

\section{DAFTAR PUSTAKA}

$\mathrm{H}$ Sirait, TA Barus, $\mathrm{H}$ Wahyuningsih, 2013, Analysis of content heavy metals in various fish species in batang toru river, Aek Pahu Tombak and Aek Pahu Hutamosu 
District South Tapanuli, - Jurnal Perikanan dan Kelautan.

PT Agincourt Resources, 2020, Laporan Addendum Andal, RKL dan RPL Kegiatan Penambahan Fasilitas Pengelolaan Tailing dan Beberapa Perubahan Operasional PT Agincourt Resources Kecamatan Batang Toru Kabupaten Tapanuli Selatan, Provinsi Sumatera Utara.

Pesce, S.F. and Wunderlin, D.A. (2000). Use of water quality indices to verify the impact of Co'rdoba City (Argentina) on Suquı'a River. Water Research, 34, 2915-2926.

Bharti, N. and Katyal, D, "Water quality indices used for surface water vulnerability assessment", Int. J. Environ.Sci., 2(1). 154-173.
Canter,L.W.,1977,Environmental Impact Assessment, McGraw-Hill, New York.

Sumitomo dan Nemerow, 1970 dalam Kepmen KLH 115, Th 2003. Pedoman Penentuan Status Mutu Air, Kementrian Lingkungan Hidup. 2004.

Republik Indonesia. 2001. Peraturan Pemerintah Nomor 82 Tahun 2001. Tentang Pengelolaan Kualitas Air Dan Pengendalian Pencemaran Air. Jakarta: Sekretaris Negara.

Republik Indonesia. 2002. Keputusan Menteri Kesehatan Nomor 907 Tahun 2002. Tentang SyaratSyarat Dan Pengawasan Kualitas Air Minum. Jakarta: Menteri Kesehatan.

Republik Indonesia. 2003. KepMen LH Nomor 115 Tahun 2001. tentang Pedoman Penentuan Status Mutu Air. Jakarta: Sekretaris Negara. 